JPSCR: Journal of Pharmaceutical Science and Clinical Research, 2020, 02, 97-109

DOI: $10.20961 /$ jpscr.v5i2.38957

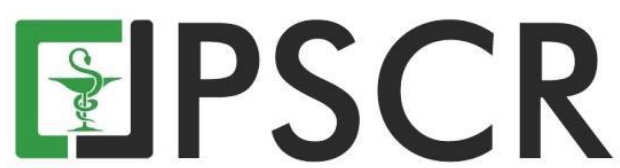

\title{
Analisis Pengendalian Persediaan Obat Dengan Metode ABC, VEN dan EOQ di Rumah Sakit Bhayangkara Kediri
}

\author{
Abdul Rofiq*, Oetari dan Gunawan Pamudji Widodo \\ Fakultas Farmasi Universitas Setia Budi, Jl. Letjen Sutoyo, Jebres, Surakarta, Jawa Tengah, Indonesia, 57127 \\ *email korespondensi: abdrofiq78@ gmail.com \\ Received 12 January 2020, Accepted 22 September 2020, Published 30 October 2020
}

\begin{abstract}
Abstrak: Pengelolaan persediaan obat yang optimal memberikan penghematan biaya pengadaan obat. Dua permasalahan sangat penting dalam pengendalian persediaan obat yaitu memutuskan jenis dan jumlah obat yang harus dipesan. Untuk mendapatkan solusi pengendalian persediaan maka diperlukan identifikasi dan analisis permasalahan tersebut. Tujuan penelitian ini menganalisis sistem pengendalian dan meningkatkan efisiensi siklus pengelolaan obat pasien BPJS Kesehatan klasifikasi AE di Instalasi Farmasi Rumah Sakit Bhayangkara Kediri. Obat klasifikasi AE menggambarkan obat dengan indek kritis tinggi dengan pemakaian dan item banyak, selanjutnya dianalisis menggunakan metode $A B C$, VEN dan EOQ. Jenis penelitian ini adalah penelitian deskriptif analitik, pengambilan data dilakukan secara retrospektif. Data yang digunakan obat pasien BPJS Kesehatan di Instalasi Farmasi Rumah Sakit Bhayangkara Kediri periode Januari - Desember 2018. Pengumpulan data primer dan sekunder melalui observasi dokumen di lapangan dan wawancara dengan pihak terkait. Analisis menggunakan metode ABC, VEN dan EOQ untuk klasifikasi obat AE. Selanjutnya hasil pengolahan data dibandingkan dengan parameter Reorder Point, Inventory Value, Inventory Turn Over Ratio, Customer Service Level, Safety Stock dan Maximum level inventory untuk menilai efisiensi pengendalian persediaan guna memperoleh persediaan obat yang efisien. Hasil penelitian menunjukkan analisis pengendalian obat pasien BPJS Kesehatan menggunakan metode $\mathrm{ABC}$ dan VEN mampu meningkatkan pengelolaan obat menjadi efektif dan efisien khususnya obat katagori AE. Data perencanaan, pengadaan dan pemakaian obat pasien BPJS Kesehatan tahun 2018 dianalisis dengan metode EOQ selanjutnya dibandingkan nilai parameter yang digunakan dapat mengurangi nilai Stock Out, tetapi efektifitas dan efisiensi pengendalian obat tidak tercapai.
\end{abstract}

Kata kunci: Pengendalian persediaan obat; BPJS Kesehatan; ABC-VEN; EOQ

\begin{abstract}
Drugs Manajemen Supply Using ABC, VEN and EOQ Methods at Bhayangkara Hospital Kediri. Optimal management of medicine supplies may provide procurement's cost saving of drug supplies. Two important problems known in inventory control are deciding to order kind of drug and amount of drug. Identification and analysis of these problems are required to get solution in inventory control. Purpose of this study was to analyze control system and improve efficiency of drug management of BPJS Kesehatan with AE classification using ABC-VEN and EOQ methods at pharmacy installation of Bhayangkara Hospital Kediri. AE classification drugs represent critically owned drugs with high nominal amounts and large quantities. This study was descriptive with retrospective data collected. Data used were BPJS Kesehatan of January - December 2018. Primary and secondary data collected by observation of documents in hospital and interviews with related department. Each indicator was compared to existing standar to assess efficiency of inventory control. The results of data processing were compared with the parameters Reorder Point, Inventory Value, Inventory Turn over Ratio, Customer Service Level, Safety Stock and Maximum inventory level. Analysis was
\end{abstract}


carried out using the $\mathrm{ABC}$ method, VEN and EOQ for classification of AE drug in order to obtain efficient medicine supplies. Results of this study were analysis on BPJS Kesehatan management with $\mathrm{ABC}$ and VEN methods might improve drug management to be more effective and efficient. Data of planning, procurement and use were analyzed by EOQ method than compared with the calculation results of parameters might be used to calculate out of stock value, but the effectiveness and efficiency of drug improvement did not occur.

Keywords: Drug Management Supply; BPJS Kesehatan; ABC-VEN; EOQ

\section{Pendahuluan}

Ketersediaan obat di rumah sakit merupakan hal yang harus diperhatikan disebabkan persediaan yang banyak mengakibatkan resiko kerusakan obat, obat kadaluwarsa cenderung mempunyai nilai tinggi (Bowersox, 2002). Bila terjadi kekurangan dapat mengganggu pelayanan dan menimbulkan keluhan pasien terutama pada pasien yang menjadi peserta Jaminan Kesehatan Nasional. Dalam rangka pemenuhan kepuasan peserta dan kemudahan layanan, BPJS Kesehatan menerapkan sistem rujukan berjenjang melalui peluncuran sistem rujukan online (Yoki dan Fazriana, 2019). Pengadaan obat dengan sistem E-catalogue juga mempengaruhi proses pengendalian persediaan. Selain itu permasalahan tingginya jumlah item obat yang tersedia perlu adanya analisis untuk meningkatkan pengelolaan persediaan yang optimal (Andryani dkk, 2015).

Faktor jumlah item obat di rumah sakit sangat banyak menyebabkan penerapan metode visual menjadi sulit, metode kontrol tambahan yaitu metode analisis $\mathrm{ABC}$ menjadi sangat diperlukan (Peterson, 2004). Analisis ABC sering dikombinasi dengan VEN (vital, essential, dan non-essential), kombinasi ini dipandang lebih efektif karena prioritas tidak hanya masalah uang tetapi tinggat kekritisanya juga ikut berperan. Analisis kombinasi ABC VEN mempunyai tujuan dan manfaat dalam efisiensi dan penyesuaian anggaran. Jenis obat kelompok A adalah obat pilihan untuk menanggulangi penyakit terbanyak, dan obat kelompok A golongan harus $\mathrm{E}$ dan sebagian V. Disamping itu diperlukan juga metode pengendalian persediaan sistem perpetual atau Economic Order Quantity (EOQ) (Satibi, 2015).

Metode EOQ dipergunakan untuk menentukan jumlah pesanan persediaan yang meminimumkan biaya pemesanan dan biaya penyimpanan (Seto, 2015). Persediaan yang tinggi berakibat resiko penyimpanan semakin besar, biaya pemeliharaan yang diperlukan juga lebih besar, meskipun dapat memperkecil biaya pemesanan dan distribusi sehingga perlu adanya optimalisasi supaya terbentuk kesetimbangan antara jumlah persediaan dengan biaya pemesanan dan distribusi (Satibi, 2015). 
Tujuan penelitian ini menganalisis sistem pengendalian dan meningkatkan efisiensi siklus pengelolaan obat pasien BPJS Kesehatan klasifikasi AE di Instalasi Farmasi Rumah Sakit Bhayangkara Kediri. Berdasarkan pengamatan di lapangan dengan diberlakukanya sistem rujukan berjenjang dan pengadaan obat menggunakan E-catalogue mempengaruhi proses perencanaan, pengadaan obat dan proses pengendalian persediaan. Selain itu permasalahan tingginya jumlah item obat BPJS Kesehatan, tingginya nilai persediaan obat pasien BPJS Kesehatan yang tersedia di Instalasi Farmasi Rumah Sakit Bhayangkara Kediri perlu adanya analisis untuk meningkatkan pengelolaan persediaan yang optimal. Penelitian sistem pengendalian dan efisiansi pengelolaan obat pasien BPJS Kesehatan pada saat diberlakukannya sistem rujukan berjenjang dan pengadaan obat menggunakan E-catalogue masih jarang dilakukan. Obat yang masuk dalam kelompok A menurut analisis ABC, dan E (essential) menurut golongan VEN, mengambarkan obat yang tingkatan kritisnya tinggi, nominal pemakaian banyak dan jumlah item tinggi. Setelah itu, akan dilakukan pemberian rekomendasi pemilihan metode pengendalian persediaan obat kategori AE supaya pengelolaan obat lebih efisien.

\section{Metode}

Jenis penelitian ini adalah penelitian deskriptif analitik, pengambilan data dilakukan secara retrospektif, data obat pasien BPJS Kesehatan yang digunakan periode Januari 2018 Desember 2018. Rancangan ini digunakan untuk mengetahui apakah terjadi peningkatan pengendalian persediaan obat pasien BPJS Kesehatan di Instalasi Farmasi Rumah Sakit Bhayangkara Kediri jika terapkan metode EOQ. Populasi dalam penelitian ini adalah data perencanaan, pengadaan dan penggunaan obat pasien BPJS Kesehatan tahun 2018 yang didapat dari Kepala Instalasi Farmasi, Kepala Pengadaan dan Kepala Gudang Rumah Sakit Bhayangkara Kediri. Sampel pada penelitian ini adalah data perencanaan, pengadaan dan penggunaan obat pasien BPJS Kesehatan tahun 2018 kelompok AE.

Unit obat yang dianalisis adalah obat oral (tablet, kaplet, kapsul, sirup), injeksi dan infus serta obat luar (salep, tetes mata, tetes telinga, suppositoria) yang termasuk dalam kelompok A dari hasil Analisis ABC, golongan E dari hasil analisis VEN sehingga didapatkan kelompok obat pasien BPJS Kesehatan klasifikasi AE yang mengambarkan obat yang tingkatan kritisnya tinggi, nominal pemakaian banyak dan jumlah item tinggi (Satibi, 2015). Analisis yang dilakukan meliputi analisis $\mathrm{ABC}, \mathrm{VEN}$, nilai persediaan, Re-Order Point (ROP), Inventory Turn Over Ratio (ITOR), Customer Service Level (CSL), Safety Stock (SS), dan Maximum Level Inventory (Deby, 2013).

Analisis obat klasifikasi AE dilakukan dengan menghitung persentase setiap item obat kemudian dikelompokkan. Jika nilai persentase 0-75\%, maka dikategorikan sebagai kelompok 
A. Jika nilai persentase berkisar antara 75-90\%, itu dikategorikan sebagai kelompok B, sedangkan persentase di kisaran 90-100\%, dikategorikan sebagai kelompok C (Satibi, 2015). Menghitung EOQ obat klasifikasi AE menggunakan persamaan 1.

$$
\mathrm{EOQ}=\frac{\sqrt{2 \mathrm{CoS}}}{\mathrm{CmV}}
$$

Persamaan 1. Rumus perhitungan EOQ obat klasifikasi AE. Keterangan: Co: Cost per order (sekali pesan) yaitu biaya telepon, kertas dan biaya SDM, Cm: Cost of maintenance atau biaya penyimpanan dari persediaan setahun dan S: jumlah permintaan setahun, $\mathrm{V}$ : Cost per unit.

Mencari Nilai Persediaan (Inventory Value) menrupakan nilai persediaan dalam rupiah, data - data yang dibutuhkan yaitu awal pemakaian obat dan sisa persediaan selanjutnya dikalikan dengan harga. Inventory Turn Over Ratio ( ITOR )untuk mengetahui perputaran anggaran obat dengan menghitung harga pokok penjualan semua obat dalam kurun waktu tertentu, kemudian dibagi dengan nilai rata-rata persediaan. Tingkat Pelayanan (Customer Service Level) dihitung jumlah resep yang dilayani, resep yang tidak terlayani juga dihitung kemudian dibandingkan jumlah resep yang terlayani dengan resep tertolak dikalikan seratus persen. Analisis Reorder Point (ROP) merupakan nilai persediaan saat pemesanan dilakukan kembali dengan persamaan $\mathrm{d} x \mathrm{~L}$, dimana $\mathrm{d}=\mathrm{D}$ / jumlah hari kerja, Jika membangun safety stock maka $\mathrm{d}=$ kebutuhan per hari, $\mathrm{D}=$ kebutuhan bulanan, $\mathrm{L}=$ waktu tenggang (lead time), $\mathrm{SS}=$ stok aman (Safety stock).

Safety Stock secara umum merupakan level pengadaan ulang atau level persediaan maksimum termasuk dalam persediaan cadangan. stok aman (Safety stock $)=($ LT x CA) dimana $\mathrm{LT}=$ Lead time (waktu tunggu dari pesan obat sampai obat datang), $\mathrm{CA}=$ Consumption Average (rata-rata penggunaan sehari atau sebulan). Maximum level inventory menunjukkan persediaan mencapai tingkatan yang maksimal. Maximum level inventory $=$ Stok minimum + (periode pengadaan $\mathrm{x}$ rata-rata penggunaan sehari).

\section{Hasil dan Pembahasan}

\subsection{Analisis ABC}

Teknik manajemen yang berguna untuk peningkatan, efektivitas dan efisiensi persediaan maka dapat digunakan analisis ABC (Pareto). Tabel 1 merupahan hasil analisis menggunakan analisis ABC. Tabel 1 pada kelompok A, B dan C, persentase jumlah item obat dan nilai pemakaian bila dibandingan dengan Satibi (2015) dimana penelitian dilaksanakan sebelum era BPJS, kelompok A merupakan obat yang menggunakan $75 \%$ total biaya dan item obatnya berjumlah $20 \%$ dari total obat. kelompok B merupakan obat yang menggunakan $15 \%$ total biaya dan item obatnya berjumlah $30 \%$ dari total obat. kelompok $\mathrm{C}$ merupakan obat yang menggunakan $10 \%$ total biaya dan item obatnya berjumlah $50 \%$ dari total obat. Jumlah item 
obat pasien BPJS Kesehatan di Instalasi Farmasi Rumah Sakit Bhayangkara Kediri menunjukkan perbedaan cukup signifikan yang disebabkan oleh terlalu banyaknya obat kelompok $\mathrm{C}$ dan sebagian besar dari obat tersebut masuk ke dalam kelompok obat slow moving.

Tabel 1.Pengelompokan Obat pasien BPJS Kesehatan dengan Metode ABC Berdasarkan Jumlah item obat, Persentase dan Nilai Pemakaian di Instalasi Farmasi Rumah Sakit Bhayangkara Kediri Tahun 2018 berdasarkan data penggunaan obat pasien BPJS Kesehatan tahun 2018.

\begin{tabular}{ccccc}
\hline Kelompok & Jumlah item obat & Persentase (\%) & Nilai Pemakaian (Rp) & Persentase (\%) \\
\hline A & 115 & 13.76 & $9,120,929,203$ & 74.98 \\
B & 125 & 14.95 & $1,826,917,255$ & 15.02 \\
C & 596 & 71.29 & $1,216,321,501$ & 10.00 \\
\hline Total & 836 & 100 & $12,164,167,959$ & 100 \\
\hline
\end{tabular}

Obat slow moving adalah produk perishable yang akan mengalami penurunan nilai setelah beberapa waktu atau mengalami kadaluarsa. Obat yang termasuk dalam kelompok slow moving akan memiliki kemungkinan lebih tinggi untuk kadaluarsa. Perencanaan dan pengendalian persediaan obat kelompok slow moving product perlu dilakukan sehingga dapat mengurangi sisa jumlah obat yang tersimpan di gudang dan menurunkan risiko obat tersebut kadaluarsa sebelum laku terjual (Alisha dan Nur, 2018). Obat golongan ini harus dilakukan penanganan lebih lanjut untuk efisiensi persediaan. Obat slow moving yang tinggi dapat meningkatkan resiko kerugian bagi rumah sakit (Satibi, 2015).

Tabel 2. Daftar 5 Besar Penggolongan Obat pasien BPJS Kesehatan dengan Metode ABC di Instalasi Farmasi Rumah Sakit Bhayangkara Kediri Tahun 2018 berdasarkan data penggunaan obat pasien BPJS Kesehatan tahun 2018.

\begin{tabular}{lcccc}
\hline \multicolumn{1}{c}{ Nama Obat } & Pemakaian (unit) & $\begin{array}{c}\text { Harga beli } \\
(\mathbf{R p})\end{array}$ & $\begin{array}{c}\text { Nilai Pemakaian } \\
(\mathbf{R p})\end{array}$ & Pareto \\
\hline Novorapid Flexpen & 5.165 & 87.000 & 449.355 .000 & $\mathrm{~A}$ \\
Levemir Flexpen & 5.045 & 78.288 & 394.962 .960 & $\mathrm{~A}$ \\
Seroquel XR 400 mg & 19.669 & 18.616 & 366.158 .104 & $\mathrm{~A}$ \\
Seroquel XR 300 mg & 21.497 & 15.548 & 334.235 .356 & $\mathrm{~A}$ \\
Inf Sanbe RL SP & 46.693 & 7.150 & 333.854 .950 & $\mathrm{~A}$ \\
\hline MST 10 mg & 1,453 & 15,620 & $22,695,860$ & $\mathrm{~B}$ \\
Hyoscine Inj & 2,714 & 8,360 & $22,689,040$ & $\mathrm{~B}$ \\
Norfion INJ 4mg/4ml & 889 & 25,520 & $22,687,280$ & $\mathrm{~B}$ \\
Curcuma & 48,652 & 462 & $22,477,224$ & $\mathrm{~B}$ \\
Lapifed TAB & 8,846 & 2,530 & $22,380,380$ & $\mathrm{~B}$ \\
\hline Durogesic Path 25 mg & 35 & 237,050 & $8,296,750$ & $\mathrm{C}$ \\
Tamoliv 1000mg inf & 296 & 27,500 & $8,140,000$ & $\mathrm{C}$ \\
Ferlin Drop & 245 & 33,110 & $8,111,950$ & $\mathrm{C}$ \\
Gamaras 20\% & 4 & $2,009,150$ & $8,036,600$ & $\mathrm{C}$ \\
Tamoliv 500mg inf & 243 & 33,000 & $8,019,000$ & $\mathrm{C}$ \\
\hline
\end{tabular}

Formularium rumah sakit yang mengakomodasi obat pasien BPJS Kesehatan mempengaruhi item obat yang masuk kelompok ABC. Penyusunan formularium rumah sakit 
juga mempertimbangkan faktor epidemiologi dimana di RS Bhayangkara Kediri didominasi oleh penderita penyakit kronis seperti diabetes, hipertensi, stoke, gangguan jiwa kronik (shizophrenia) dan gangguan jantung. Jika diambil 5 besar urutan teratas dari obat kelompok A, B dan C tersaji data seperti tabel 2.

Berdasarkan tabel 2, kelompok A obat yang mempunyai harga mahal dan penggunaan dalam jumlah tinggi, begitu juga untuk obat prevalensi tinggi meskipun harganya tidak terlalu mahal. Obat dengan prevalensi tinggi tetapi harganya murah akan masuk kelompok B, obat dengan harga tinggi pemakaian sedang akan masuk kelompok B. Obat dengan prevalensi tinggi dengan harga sangat murah akan masuk kelompok $\mathrm{C}$, obat dengan harga tinggi tetapi jarang pemakaian akan masuk kelompok $\mathrm{C}$.

\subsection{Analisis Kombinasi ABC VEN}

Analisis kombinasi ABC dan VEN bertujuan memberikan manfaat dan efisiensi dalam menyesuaikan anggaran pengadaan obat di rumah sakit. Dasar pengolongan obat menjadi VEN (Vital, Esensial dan Non esensial) ditentukan oleh Faktor makro (antara lain peraturan pemerintah, data epidemiologi wilayah) dan faktor mikro (antara lain jenis pelayanan kesehatan yang tersedia di rumah sakit tempat dilakukan penelitian) (Satibi,2015). Data yang diolah dapat dilihat pada tabel 3 .

Tabel 3. Hasil Analisis VEN item obat pasien BPJS Kesehatan di Instalasi Farmasi Rumah Sakit Bhayangkara Kediri tahun 2018.

\begin{tabular}{lcc}
\hline \multirow{2}{*}{ Golongan } & \multicolumn{2}{c}{ Item Obat } \\
\cline { 2 - 3 } & Jumlah & Persentase (\%) \\
\hline Vital & 14 & 12,17 \\
Esensial & 84 & 73,05 \\
Non esensial & 17 & 14,78 \\
\hline Total & $\mathbf{1 1 5}$ & $\mathbf{1 0 0}$ \\
\hline
\end{tabular}

Pengelompokan VEN diperoleh dari wawancara dengan Kepala Instalasi Farmasi, Kepala Gudang dan Kepala Perencanaan dan Pengadaan obat di rumah sakit tersebut. Pola penyakit dan standar pengobatan digunakan dalam menentukan pengelompokan VEN (Maimun, 2008). Ada perbedaan pendapat pada penetapan kelompok E diantara kepala instalasi farmasi, kepala perencanaan dan kepala gudang sehingga dalam penelitian ini hanya dipertimbangkan hasil wawancara dengan kepala Instalasi Farmasi Rumah Sakit Bhayangkara Kediri.

Rumah Sakit Bhayangkara Kediri dalam penyediaan obat pasien BPJS Kesehatan menggunakan metode konsumsi sesuai data kebutuhan obat tahun lalu di bulan yang sama dan mempertimbangkan jumlah pasien pada bulan ini, perhatian khusus pada obat untuk penyakit 
dengan prevalensi tinggi diantaranya adalah diabetes, hipertensi, stoke, gangguan jiwa (shizophrenia) dan jantung. Obat ini disediakan untuk kebutuhan tiga bulan dengan pertimbangan fast moving dan menghindari kekosongan persediaan di PBF. Bila terjadi kekosongan obat akan subtitusi dengan obat lain yang indikasinya sama beda merk dagangnya.

Berdasarkan tabel 3, jika jumlah obat dan persentase dibandingkan dengan penelitian Agnes dkk (2017) di rumah sakit tipe B di Jakarta memberikan hasil yang berbeda. Agnes dkk (2017) mendapatkan data dari total 129 item obat didapat golongan V sebanyak 17 item obat $(13,18 \%)$, golongan E 43 item obat $(33,33 \%)$ dan golongan N 11 item obat $(53,49 \%)$. Hasil penelitian menunjukkan perbedaan jumlah item obat yang termasuk golongan V, E dan N. Hal ini disebabkan oleh pedoman penentuan VEN yang berbeda, epidemiologi wilayah dan ragam layanan kesehatan yang disediakan rumah sakit yang bersangkutan.

Tabel 4. Daftar 5 Besar Obat pasien BPJS Kesehatan Klasifikasi AE di Instalasi Farmasi Rumah Sakit Bhayangkara Kediri tahun 2018.

\begin{tabular}{lccc}
\hline Nama Obat & Pemakaian (unit) & Harga beli (Rp) & Nilai Pemakaian (Rp) \\
\hline Novorapid Flexpen & 5,165 & 7,000 & $449,355,000$ \\
Levemir Flexpen & 5,045 & 78,288 & $394,962,960$ \\
Inf Sanbe RL SP & 46,693 & 7,150 & $333,854,950$ \\
Clopidogrel & 235,869 & 1,318 & $310,875,342$ \\
Beclov 250 mg inj & 18,643 & 13,308 & $248,101,044$ \\
\hline
\end{tabular}

Berdasar tabel 4 nilai pemakaian insulin menempati posisi teratas, hal ini sejalan dengan pola penyakit terbanyak yang terlayani di Rumah Sakit Bhayangkara Kediri. Obat kronis sering diresepkan kepada pasien untuk kebutuhan satu bulan, selanjutnya pasien dapat melakukan kontrol ulang jika persediaan obat habis. Clopidogrel dan beclov termasuk obat-obat yang paling sering diresepkan untuk penanganan stroke. Beclov (Citicoline) memiliki efek terapi pada beberapa tahap kaskade iskemik pada stroke iskemik akut dan telah menunjukkan efisiensi dalam beragam model hewan stroke akut. Perawatan jangka panjang dengan citicoline aman dan efektif, meningkatkan penurunan kognitif pasca stroke dan meningkatkan pemulihan fungsional pasien (Jose, 2013). Clopidogrel dapat dipilih dalam merawat penyakit kardiovaskular terutama dalam mengurangi kejadian stroke, MI, atau vaskular penyakit (Titien, 2017).

Pengadaan obat pasien BPJS Kesehatan di Instalasi Farmasi Rumah Sakit Bhayangkara Kediri dilakukan 1-3 kali dalam sebulan, metode yang digunakan berdasarkan kebutuhan obat per minggu dengan metode konsumsi tanpa adanya analisis perencanaan yang tepat. Metode ini digunakan berdasarkan data real konsumsi obat pada periode yang lalu, ketersediaan obat di PBF menjadi perimbangan faktor penentu. Perhitungan jumlah obat yang dibutuhkan melalui 
cara mengumpulkan, mengolah dan analisa data yang diperlukan untuk informasi, evaluasi, perhitungan rancangan, dan menyesuaikan dengan ketersediaan dana.

\subsection{Economic Order Quantity (EOQ)}

Keuntungan dari sistem EOQ adalah jika terjadi kenaikan permintaan yang mendadak maka masih memungkinkan untuk melaksanakan respon dengan cepat. Sistem EOQ ini memerlukan catatan persediaan yang akurat, catatan persediaan selalu diperbaharui, komunikasi, dan pelayanan yang baik dengan distributor atau pemasok serta dibantu dengan penggunaan sistem informasi manajemen.

Tabel 5. Jumlah Pemakaian, Harga beli, Biaya Pemesanan, Biaya Penyimpanan dan perhitungan Economic Order Quantity (EOQ) daftar 5 Besar Obat pasien BPJS Kesehatan Klasifikasi AE di Instalasi Farmasi Rumah Sakit Bhayangkara Kediri tahun 2018.

\begin{tabular}{lccccc}
\hline \multicolumn{1}{c}{ Nama Obat } & $\begin{array}{c}\text { Pemakaian } \\
\text { (unit) }\end{array}$ & $\begin{array}{c}\text { Harga } \\
\text { beli (Rp) }\end{array}$ & $\begin{array}{c}\text { Biaya } \\
\text { Pemesanan } \\
(\mathbf{R p})\end{array}$ & $\begin{array}{c}\text { Biaya } \\
\text { Penyimpanan } \\
\mathbf{1 7 \%} \text { (Rp) }\end{array}$ & $\begin{array}{c}\text { EOQ } \\
\text { (Unit) }\end{array}$ \\
\hline Novorapid Flexpen & 5,165 & 87,000 & 3.302 & 14,790 & 48 \\
Levemir Flexpen & 5,045 & 78,288 & 3.302 & 13,309 & 50 \\
Inf Sanbe RL SP & 46,693 & 7,150 & 3.302 & 1,216 & 504 \\
Clopidogrel & 235,869 & 1,318 & 3.302 & 224 & 2,637 \\
Beclov 250 mg inj & 18,643 & 13,308 & 3.302 & 2,262 & 233 \\
\hline
\end{tabular}

EOQ masing-masing obat untuk pengendalian persediaan, jika dibandingkan dengan data real pengadaan obat menunjukkan bahwa model yang digunakan pada pengadaan obat di Instalasi Farmasi Rumah Sakit Bhayangkara Kediri tanpa analisa EOQ (Tabel 5), pengadaan obat lebih rendah atau lebih tinggi dari EOQ menyebabkan alokasi anggaran, biaya pemesanan dan biaya penyimpanan yang tidak tepat sehingga dapat menimbulkan kekosongan ataupun kelebihan stok obat. Metode EOQ bila diterapkan dengan benar akan dapat menurunkan biaya penyimpanan, resiko kerusakan obat dan menurunkan angka kadaluarsa obat (Quick et. Al, 2012).

\section{A. Analisis Reorder Point (ROP)}

ROP dan EOI mempunyai arti penting dalam pengendalian persediaan supaya dapat menjamin ketersediaan obat sehingga pada saat yang tepat proses pemesanan obat dapat dilaksanakan, yaitu pada saat stok obat tidak kosong dan tidak berlebih.

Pengadaan obat di Instalasi Farmasi Rumah Sakit Bhayangkara Kediri tidak sesuai (Tabel 6) karena tidak menggunakan metode analisa ROP dadn EOI, pengadan obat hanya berdasarkan data kebutuhan obat minggu lalu, penentuan sisa stok tidak berdasar stok aman sesuai perhitungan pada tabel 6 tetapi hanya melihat ketersedian obat di PBF, ketersediaan dana 
dan pengadan obat tidak sesuai dengan EOI karena pengadaan obat dilaksanakan tiga kali dalam setiap bulan dan jika ada kegiatan yang insidentil makan pengadaan obat dapat dilakukan tanpa perencenaan. Penentuan ROP akan menjamin ketersediaan obat pasien BPJS Kesehatan, walaupun terjadi kenaikan pemakaian, ataupun keterlambatan pengiriman obat pasien BPJS Kesehatan. Pengawasan terhadap persediaan harus dapat dilaksanakan secara efektif sehingga jika dketahui banyaknya suatu item obat akan dipesan, pesanan ulang kapan dilakukan terhadap item tersebut, dan item-item obat mana saja yang perlu dilakukan pengawasan maka bisa dikatakan efektif.

Tabel 6. Perhitungan Lead Time, Safety Stock, EOI dan ROP daftar 5 Besar Obat pasien BPJS Kesehatan Klasifikasi AE di Instalasi Farmasi Rumah Sakit Bhayangkara Kediri tahun 2018.

\begin{tabular}{lcccc}
\hline Nama Obat & Lead Time (hari) & SS (unit) & $\begin{array}{c}\text { EOI } \\
\text { (hari) }\end{array}$ & $\begin{array}{c}\text { ROP } \\
\text { (unit) }\end{array}$ \\
\hline Novorapid Flexpen & 2 & 28 & 4 & 57 \\
Levemir Flexpen & 2 & 28 & 4 & 55 \\
Inf Sanbe RL SP & 2 & 256 & 4 & 512 \\
Clopidogrel & 2 & 1,292 & 4 & 2,585 \\
Beclov 250 mg inj & 2 & 102 & 5 & 204 \\
\hline
\end{tabular}

\section{B. Analisis Nilai Persediaan}

Nilai pengadaan tidak ada yang sesuai dengan perencanaan, dalam hal ini dipengaruhi oleh ketersediaan barang di distributor, kebutuhan obat di luar perencanaan dan dipengaruhi juga oleh perubahan kebijakan perlakuan terhadap pasien BPJS Kesehatan (Tabel 7). Sistem pengadaan di Rumah Sakit Bhayangkara Kediri pada obat-obat E-catalogue terkendala tidak adanya daftar obat di dalamnya, pemesanan tidak direspon oleh industri farmasi dan PBF sementara kebutuhan obat sudah mendesak, waktu pengiriman obat terlalu lama, penolakan oleh industri farmasi dan PBF karena stok obat tidak tersedia. Menurut Wijaya dkk (2019) masalah yang sering terjadi dalam pengadaan adalah jadwal pengiriman pesanan obat tidak menentu, obat masuk daftar e-catalogue tetapi stok dari pabrik kosong sehingga, batas minimal nilai pengadaan yang dipersyaratkan sehingga nilai pesenan tidak sama dengan perencanaan, respon penyedia yang lama terhadap pemesanan, obat tidak da dalam daftar $e$-catalogue, jumlah tenaga kefarmasian yang tidak mencukupi sebagai pejabat pengadaan obat.

Nilai perencanaan berbeda dengan nilai pengadaan, begitu juga sebaliknya nilai pengadaan berbeda dengan nilai perencanaan (Tabel 7). Hal ini terjadi disebabkan pada saat perencanaan kebutuhan obat kemudian dilakukan pemesanan obat, distributor tidak mampu melayani pemesanaan obat tersebut disebabkan adanya kekosongan stok di PBF. Sewaktu PBF mempunyai stok maka berdasarkan pesanan yang belum terlayani PBF tersebut akan mengirimkan pesanan dan biasanya pengiriman di bulan yang berbeda dengan pemesanan. 
Karena ketersediaan stok obat di PBF tidak selalu ada kadang juga dilakukan perencanaan dan pengadaan obat-obat tertentu untuk kebutuhan 2- 3 bulan pemakaian, hal ini menyebabkan nilai persediaan tinggi.

Tabel 7. Analisis nilai perencanaan, pengadaan dan persediaan di Instalasi Farmasi Rumah Sakit Bhayangkara Kediri tahun 2018.

\begin{tabular}{crcr}
\hline Bulan & Nilai Perencanaan (Rp) & Nilai Pengadaan (Rp) & Nilai Persediaan(Rp) \\
\hline & & & \\
Januari & 500.568 .439 & 856.531 .498 & 1.491 .563 .874 \\
Februari & 627.919 .676 & 1.111 .847 .968 & 1.414 .325 .456 \\
Maret & $1,023,106,123$ & 1.499 .273 .815 & 1.713 .070 .525 \\
April & $733,075,706$ & 1.001 .005 .294 & 1.484 .626 .071 \\
Mei & $1,377,862,708$ & 1.647 .872 .439 & 2.090 .899 .228 \\
Juni & $1,328,148,179$ & 609.222 .066 & 1.854 .614 .506 \\
Juli & $1,501,635,463$ & 1.694 .273 .514 & 2.160 .747 .546 \\
Agustus & $966,722,299$ & 1.050 .326 .777 & 2.113 .999 .337 \\
September & $1,446,109,080$ & 1.022 .951 .729 & 2.161 .867 .549 \\
Oktober & $935,736,837$ & 1.469 .658 .756 & 2.306 .904 .886 \\
November & $1,015,177,661$ & 1.010 .828 .948 & 2.242 .113 .740 \\
Desember & $692,289,703$ & 817.106 .599 & 1.915 .738 .093 \\
\hline
\end{tabular}

\section{Analisis Inventory Turn Over Ratio (ITOR)}

Analisis Inventory Turn Over Ratio (ITOR) di Instalasi Farmasi Rumah Sakit Bhayangkara Kediri tahun 2018 ditunjukkan pada tabel 8. Hasil analisis ITOR jika dibandingkan dengan penelitian Wirdah dkk (2013) di RSUD Karel Sadsuitubun Maluku diperoleh ITOR 5,77 kali dan menurut Pudjaningsih (1996) indikator ITOR rumah sakit 8-12 kali. Masih rendahnya nilai ITOR menunjukkan bahwa pengendalian persedian masih tidak efektif dan terjadi penumpukan persediaan obat di gudang dalam jumlah berlebih. Hal ini disebabkan beberapa hal antara lain tidak adaya analisis pengendalian persediaan dengan metode ABC, EOQ, ROI dan EOI.

\section{Tingkat Pelayanan (Customer Service Level)}

Nilai tingkat pelayanan di Instalasi Farmasi Rumah Sakit Bhayangkara Kediri (Tabel 9) menunjukkan hasil yang optimal, tingkat keterlayanan resep tinggi. Hal ini sesuai dengan penelitian Nur dkk (2013) di Instalasi Farmasi Rumah Sakit Lasinrang Kabupaten Pinrang Sulawesi Selatan dimana CSL sebelum dilakukan intervensi nilainya 99,65\% dan setelah dilakukan intervensi menjadi 99,93\%. Instalasi Farmasi Rumah Sakit Bhayangkara Kediri menerapkan sistem substitusi obat dengan persetujuan dokter penulis resep jika terjadi kekosongan persediaan yang sesuai dengan resep dokter tersebut. Juga dilakukan substitusi terhadap obat-obat yang tidak sesuai dengan formularium obat pasien BPJS Kesehatan di Rumah Sakit Bhayangkara Kediri. Apoteker berhak mengganti obat yang tidak sesuai dengan 
obat sejenis yang ada di formularium BPJS Kesehatan Rumah Sakit Bhayangkara Kediri. Terhadap resep dengan permintaan obat dalam jumlah banyak dilakukan pelayanan tunda. Pelayanan tunda yaitu permintaan obat dengan jumlah banyak di dalam suatu resep, dilayani untuk 5-7 hari sedangkan sisa obat yang belum terlayani diberikan copy resep untuk mengambil sisa obat yang belum terlayani, sehingga pasien tetap mendapatkan obat sesuai resep.

Tabel 8. Analisis harga pokok pembelian, nilai persediaan dan Inventory Turn Over Ratio (ITOR) di Instalasi Farmasi Rumah Sakit Bhayangkara Kediri tahun 2018.

\begin{tabular}{cccc}
\hline Bulan & $\begin{array}{c}\text { Harga Pokok Pembelian } \\
(\mathbf{R p})\end{array}$ & $\begin{array}{c}\text { Nilai Persediaan } \\
(\mathbf{R p})\end{array}$ & ITOR (kali) \\
\hline Januari & $1,142,408,127$ & 1.491 .563 .874 & 0,76 \\
Februari & $1,165,182,087$ & 1.414 .325 .456 & 0,82 \\
Maret & $1,191,341,517$ & 1.713 .070 .525 & 0,69 \\
April & $1,217,225,552$ & 1.484 .626 .071 & 0,82 \\
Mei & $1,055,546,102$ & 2.090 .899 .228 & 0,50 \\
Juni & $866,456,606$ & 1.854 .614 .506 & 0,46 \\
Juli & $1,329,779,115$ & 2.160 .747 .546 & 0,62 \\
Agustus & $1,074,201,774$ & 2.113 .999 .337 & 0,51 \\
September & $966,319,256$ & 2.161 .867 .549 & 0,45 \\
Oktober & $1,325,981,083$ & 2.306 .904 .886 & 0,57 \\
November & $1,062,194,312$ & 2.242 .113 .740 & 0,47 \\
Desember & $1,156,229,340$ & 1.915 .738 .093 & 0,60 \\
\hline
\end{tabular}

Tabel 9. Nilai tingkat Pelayanan (Customer Service Level) di Instalasi Farmasi Rumah Sakit Bhayangkara Kediri tahun 2018.

\begin{tabular}{cccc}
\hline Bulan & Jumah Resep Terlayani & Jumlah Seluruh Resep & CSL (\%) \\
\hline Januari & 12.543 & 12.646 & 99.19 \\
Februari & 14.060 & 14.156 & 99.32 \\
Maret & 16.239 & 16.409 & 98.96 \\
April & 16.998 & 17.142 & 99.16 \\
Mei & 15.075 & 15.208 & 99.13 \\
Juni & 11.267 & 11.356 & 99.22 \\
Juli & 16.854 & 16.985 & 99.23 \\
Agustus & 14.773 & 14.885 & 99.25 \\
September & 12.099 & 12.190 & 99.25 \\
Oktober & 17.015 & 17.174 & 99.07 \\
November & 12.089 & 12.177 & 99.28 \\
Desember & 13.783 & 13.881 & 99.29 \\
\hline
\end{tabular}

\section{E. Safety Stock (SS) dan Maximum level inventory}

Stok akhir obat di Instalasi Farmasi Rumah Sakit Bhayangkara Kediri (Tabel 10) menunjukkan bahwa sistem perencanaan dan pengadaaan tidak menggunakan metode yang sesuai, sehingga hasilnya tidak sesuai dengan nilai maksimum berdasarkan perhitungan paramater. Dampak yang ditimbulkan jika stok berlebih menyebabkan nilai persediaan menjadi tinggi, biaya pengelolaan dan penyimpanan tinggi. Dana yang dikeluarkan oleh rumah sakit menjadi lebih besar untuk proses pengadaan obat BPJS Kesehatan. Resiko yang ditimbulkan 
akibat persediaan yang besar adalah kerusakan obat dan timbulnya obat kadaluarsa. Sebaliknya jika nilai persediaan rendah dapat menimbulkan pelayanan resep terganggu dan terjadi stock out.

Tabel 10. Safety stock (SS), Maximum, Minimum level inventory dan Stok Akhir di Instalasi Farmasi Rumah Sakit Bhayangkara Kediri tahun 2018.

\begin{tabular}{lcccc}
\hline \multicolumn{1}{c}{ Nama Obat } & SS (unit) & Minimum (unit) & Maksimum (unit) & $\begin{array}{c}\text { Stok akhir } \\
\text { (unit) }\end{array}$ \\
\hline Novorapid Flexpen & 28 & 57 & 156 & 289 \\
Levemir Flexpen & 28 & 55 & 152 & 159 \\
Inf Sanbe RL SP & 256 & 512 & 1,407 & 1,627 \\
Clopidogrel & 1,292 & 2,585 & 7,108 & 34,431 \\
Beclov 250 mg inj & 102 & 204 & 562 & 1,624 \\
\hline
\end{tabular}

\section{Kesimpulan}

Penelitian ini diperoleh hasil analisis pengendalian obat pasien BPJS Kesehatan menggunakan metode ABC dan VEN mampu meningkatkan pengelolaan obat menjadi efektif dan efisien khususnya obat katagori AE. Data perencanaan, pengadaan dan pemakaian obat pasien BPJS Kesehatan tahun 2018 dianalisis dengan metode EOQ selanjutnya dibandingkan nilai parameter yang digunakan dapat mengurangi nilai Stock Out, tetapi efektifitas dan efisiensi pengendalian obat tidak tercapai.

\section{Ucapan Terima Kasih}

Penulis mengucapkan terima kasih kepada Rumah Sakit Bhayangkara Kediri, Universitas Setia Budi dan Staf Instalasi Farmasi Rumah sakit Bhayangkara Kediri yang membantu proses pengumpulan data dan proses pengerjaan sehingga penelitian dapat diselesaikan.

\section{Deklarasi Konflik Kepentingan}

Semua penulis menyatakan tidak ada konflik kepentingan terhadap naskah ini.

\section{Daftar Pustaka}

Alisha Hutami, Nur Mayke Eka Normasari. (2018). Analisis Perencanaan Persediaan Obat Kelompok Slow Moving Product Pada Layanan Farmasi dI Yogyakarta, Tesis, Universitas Gadjah Mada Yogyakarta.

Andryani Ningsih, Achmad Fudholi, Sumarni. (2015). Hubungan Penerapan Elektronik Katalog Terhadap Efisiensi Pengadaandan Keersediaan Obat, Jurnal Manajemen dan Pelayanan Farmasi, 5:241-248.

Agnes, S., Erna, K., Agastya. (2017). Identifikasi Faktor yang Mempengaruhi Total Biaya Inventori Obat-obatan Golongan A di Rumah Sakit Swasta Tipe B di Jakarta Tahun 2015, Medicoeticolegal dan Manajemen Rumah Sakit, 6 (1): 1-8.

Bowersox, D.J. (2002). Supply Chain Logistics Management, New York: The McGraw-Hill Companies, Inc.

Deby, (2013). Pengaruh Pengendalian Obat dengan Analisis ABC, EOQ dan ROP Terhadap Efisiensi Pengelolaan Obat Askes Klasifikasi A di Instalasi Farmasi Rumah Sakit Undata Palu, Tesis, Program Studi S2 Ilmu Farmasi Universitas Setia Budi Surakarta. 
Jose Alvares-Sabin., Gustavo C. Roman. (2013), The Role of Citicoline in Neuroprotection and Neurorepair in Ischemic Stroke, Brain Sciences,_3(3), 1395-1414.

Maimun Ali. (2008) Perencanaan Obat Antibiotik Berdasarkan Kombinasi Metode Konsumsi dengan Analisis ABC dan Reorder Point terhadap Nilai Persediaan dan Turn Over Ratio di Instalasi Farmasi RS. Darul Istiqomah Kaliwungu Kendal. Semarang.Tesis.Universitas Diponegoro

Nur Aeni Hartih, Satibi, Gunawan Pamudji Widodo. (2013), Penerapan Metode Economic Order Quantity dan Reorder Point dalam Meningkatkan Efisiensi Persediaan Obat Reguler di Instalasi Farmasi Rumah Sakit, Jurnal Manajemen dan Pelayanan Farmasi, Volume 3 (4):249-254.

Peterson, A.M. (2004). Managing Pharmacy Practise: Principles, Strategies, and System. Danvers: CRC Press.

Pudjaningsih, D, (1996), Pengembangan Indikator Efisiesi Pengelolaan Obat di Farmasi Rumah Sakit, Tesis, Fakultas Farmasi Pasca Sarjana Universitas Gadjah Mada, Yogyakarta

Seto. (2015). Manajemen Apoteker. Surabaya: Universitas Airlangga.

Satibi. (2015). Manajemen Obat di Rumah Sakit. Yogyakarta: Gadjah Mada University Press.

Titien Siwi Hartayu, Dewi Setyaningsih. (2017), Efektivitas Clopidogrel Sebagai Antitrombotik Dibandingkan Terhadap Clopidine dan Aspirin (Meta-Analysis), Jurnal Farmasi Sains dan Komunitas, 16, 65-73

Quick, J.P., Rankin, Dias, Vimal. (2012). Inventory Management in Managing Drug Supplay. Third Edition. Managing Access to Medicines and Health Technologies. Arlington: Management Sciences for Health

Yoki Muchsam, Fazriana Mareta. (2019). Analisis Pengaruh Kepahaman Sistem Rujukan Online Peserta BPJS Terhadap Kepuasan Pelayanan BPJS. Seminar Nasional Informatika Medis (SNIMed). ISSN: 2339-2207

Wijaya Andi Saputra, Diah Ayu Puspandari, M. Faozi Kurniawan. (2019), Evalusi Pengadaan Obat dengan E-Puschasing Melalui E-Catalogue di Rumah Sakit Jiwa Grhasia Daerah Istimewa Yogyakarta tahun 2017-2018, Jurnal Kebijakan Kesehatan Indonesia: JKK, 08 113-120.

Wirdah Wati R., Achmad Fudholi, Gunawan Pamudji. (2013) Evaluasi Pengelolaan Obat dan Strategi Perbaikan dengan Metode Hanlon di Instalasi Farmasi Rumah Sakit Tahun 2012. Jurnal Manajemen dan Pelayanan. 3 (4).

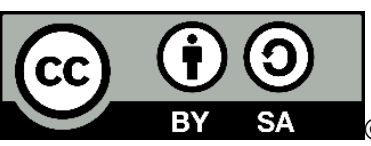

2020 by the authors. Submitted for possible open access publication under the terms and conditions of the Creative Commons Attribution-ShareAlike 4.0 International (CC BY-SA 4.0) license (https://creativecommons.org/licenses/by-sa/4.0/). 